\title{
Re-Negotiating the Post-Cold War International Order: Russian Diplomacy under Putin - Strategy, Methods, and Instruments
}

\author{
By Yannis A. Stivachtis* \& Chelsea Manning ${ }^{\dagger}$
}

\begin{abstract}
This article analyses Russia's diplomatic strategy for re-negotiating the postCold War international order. After identifying and discussing the objectives of the Russian diplomacy under Putin, the article explores the diplomatic methods and instruments employed by Moscow to achieve the Russian diplomatic goals. The article argues that Russia has employed an active diplomatic strategy with both multilateral and bilateral components, as well as a diplomatic expansion strategy as a means to expand its diplomatic space and consequently its political influence. Particular attention is given to the coercive and collaborative elements of Russian diplomatic strategy; the diplomatic methods employed by Moscow including conference and summit diplomacy; and the diplomatic instruments utilized by Russia, such as economic diplomacy, defence diplomacy, and public diplomacy.
\end{abstract}

Keywords: Russia, Diplomacy, Diplomatic Theory, Diplomatic Strategy, Multi-Polarity, Diplomatic Methods, Multilateralism, Bilateralism, Diplomatic Instruments.

\section{Introduction}

Following the collapse of the Soviet Union, Russia sought to develop collaborative relations with the West and regarded its participation in Westerndominated multilateral organizations to be fundamental for its reintegration into the international community (Tsygankov 2016, 59). As President Boris Yeltsin declared, Russia's foreign policy priority was the integration of the country into the 'community of civilized states' (Timmermann 1992; Stivachtis 2015). It was during the 1990s that Russia was admitted to the International Monetary Fund (IMF) (1992), the Council of Europe (1996) and to the Group of 7 (G-7) (1997); signed comprehensive agreements with the European Union (EU) (1994) and NATO (1997); and displayed a very cooperative attitude within the Organization for Security and Cooperation in Europe (OSCE). Russia also inherited its permanent seat at the UN Security Council from the USSR but due to Yeltsin's commitment to work closely with the West, Moscow rarely used its veto power. To this, one should add Russia's support for the War on Terror (Tsygankov 2012, 118).

However, Russia's dissatisfaction with the West began growing as a result of a set of issues: first, the policies of the EU and NATO in the Balkans following the disintegration of Yugoslavia and in total disregard of Russia's positions

*Director, International Studies Program, Virginia Tech, USA.

${ }^{\dagger} \mathrm{PhD}$ Student, University of Delaware, USA. 
(Makarychev and Morozov 2011, 353); second, the criticism that Moscow received due to its actions in Chechnya (1994); third, the growing Western involvement in the post-Soviet space (Hunter 1996; Rumer, Trenin and Zhao 2007); fourth, NATO's eastern enlargement (Tsygankov 2012, 172); and most importantly, the war in Kosovo which destroyed Moscow's trust in Western policies and paved the way toward a more assertive foreign policy. As Morozov $(2008,153)$ has pointed out, what the West called a 'new international community', in Russia's view this was a club-like group of Western states that claimed to "incarnate an allegedly indisputable perspective for the entire humankind." For Russia, the NATO intervention in the Balkans was a perfect example of the imposition of "Western rules on neighbouring territories" (Makarychev and Morozov 2011, 354).

As a result, the Kremlin put forward an alternative model of international order based on multi-polarity and sought to employ a set of diplomatic strategies, methods, and instruments to achieve this goal. In doing so, Russia sought not only to maintain its status as a great power but also to re-negotiate the principles and structure of the post-Cold War international order. The purpose of this paper is to utilize diplomatic theory (Steiner 2018; Sharp 2011; Hamilton and Langhorne 2010) to explore Russia's diplomatic strategy aimed at achieving Moscow's foreign policy objectives. In doing so, the paper is divided into five sections (including the introduction). Since the formulation of a diplomatic strategy presupposes the existence of diplomatic objectives, the second section identifies and discusses Russia's diplomatic goals. The third section examines Moscow's diplomatic strategy while the fourth and fifth sections focus respectively on the diplomatic methods and instruments employed by Moscow to achieve Russia's diplomatic objectives.

\section{Russia's Diplomatic Objectives}

Since the collapse of the Soviet Union, Russia's primary diplomatic goals have been: first, to maintain its status and prestige as a great power; second, to participate in the management of international affairs on an equal footing with Western powers and especially the United States (US); and third, to reduce the influence and presence of Western countries in the former Soviet space. This latter concern was significantly enhanced by the prolonged presence of US military bases in Central Asia, following the terrorist attacks of September 11, 2001 (Rumer, Trenin and Zhao 2007). The popular uprisings in Georgia (2003), Ukraine (2004), and Kyrgyzstan (2005) further increased Russia's fears about outside interference, especially since the new leadership in Ukraine and Georgia sought to strengthen ties with the EU and the United States. These incidents helped to shape Russia's multilateral diplomatic engagement with the Eurasian states (Malfliet, Verpoest and Vinokurov 2007) but also towards the outside powers engaging in the Eurasian region (Tsygankov 2016, 177).

The kind of international order envisaged by the Russian doctrine of 'multipolarity' constitutes to a large extent a reaction against what has been termed 
Western 'collective unilateralism' (Makarychev and Morozov 2001, 354). However, the doctrine of 'multi-polarity' has often been used to legitimize Russian unilateral policies that are designed as countermeasures to the alleged interventionism of the West. In addition, the Russian doctrine of 'multi-polarity' have produced regional and global multilateral outcomes which are viewed as balancing exercises aimed at the creation of the alternative centres of power (Tsygankov 2016, 103; Makarychev and Morozov 2001, 355).

The idea of 'multi-polarity' represents an image of the ideal future world order for Russia and became a practical policy goal during Evgeny Primakov's service initially at the Russian Foreign Ministry (1996-1998) and later as Prime Minister (1998-1999) (Tsygankov 2016, 107). However, it gained political legitimacy after the war in Kosovo and especially when Vladimir Putin became President. The most vocal declaration of the Russian doctrine of 'multi-polarity' is the famous speech by President Putin at the Munich Conference on Security Policy in February 2007, where he described the 'unipolar world' promoted by the West as "a world of one master, one sovereign" (Putin 2007). Putin argued that "unilateral, illegitimate actions" of the US and its allies are detrimental to global security because they produce new conflicts and wars, intensify the nuclear arms race, and lead to a situation where "no-one feels secure" (Putin 2007). Therefore, the remedy that Putin suggested was a multipolar world where great powers were to collectively engage in the management of world affairs.

Putin's doctrine of multi-polarity is characterized by three important features (Lee 2010, 34). First, it implies a 'collective leadership of leading states,' which assumes a special responsibility for the management of world affairs. However, this responsibility is only to apply to matters and issues that go beyond Russia's 'near abroad' as the latter is seen as falling exclusively under Moscow's control. Second, it implies that this 'collective policy' is to be negotiated among the relevant nations, including Russia. This means that Moscow would not accept the legitimacy of the outcome of negotiations in any diplomatic setting (including NATO and the EU) where it had not been part of the decision-making and would not accept a decision that it had not endorsed. In his Munich speech, Putin particularly attacked and dismissed any use of force against third countries by the EU and NATO and argued that this right belongs only to the United Nations (UN). It is not, therefore, surprising that Moscow focuses on the UN as the single most important global organization to institutionalize and practice the doctrine of 'multipolarity'. Third, 'multi-polarity' is intended to become the foundation of global order and reflects the distribution of power in the emerging multi-polar world. Thus 'multi-polarity' was to embrace the three fast-growing powers, namely China, India and Brazil. Russia's endorsement of the BRICS is indicative of this aspect of Moscow's policy of multilateralism. In sum, in Kremlin's view, the UN Security Council, the NATO-Russia Council, as well as Russia's participation in club-like international entities, such as the G-7/8 exemplify the doctrine of 'multipolarity' in practice.

However, Russia's doctrine of 'multi-polarity' does not correspond to an interest-based policy reminiscent of the $19^{\text {th }}$ century 'concert of powers'. As it was understood by Hedley Bull (1977, 194-221), great power management functions 
as a mechanism for coordinating policies and strategies of key powers which requires the exercise of restrain and responsibility everywhere and not only beyond the agreed or self-proclaimed spheres of influence. As Bull has argued, spheres of influence "confer only limited and specific rights, not 'a free hand", (Bull 1977, 217). For the same reason, Russia's doctrine of 'multi-polarity' does not correspond to the Western understanding of multilateralism as a means to greater value-based convergence of policies of the countries concerned.

The key characteristics of the Russian concept of 'multi-polarity', which has also been termed 'instrumental multilateralism' include: first, the importance of Moscow's influence/dominance in the former Soviet area as a means of globally enhancing Russia' great-power status; second, an active, goal-oriented, and pragmatic Russian diplomatic engagement in the 'near abroad'; third, efforts to balance the introduction of market principles with the perceived imperative to entrench Russian leadership; fourth a reactive and competitive regional multilateralism in response to the encroachment of 'Western' multilateral bodies; and finally, efforts that are supported by bilateralism and informal relationships between the heads of state in the Eurasian region (Lee 2010, 38).

In this context, Russia's efforts to defend its sphere of influence highlight the link between global and regional geopolitics. Influence in the former Soviet republics not only serves immediate Russian national interests (such as safeguarding Russian exports to neighbouring markets and enhancing national security by including neighbouring countries in Russian-dominated security structures), but also adds weight to Russia's claim to its great-power status (Lee 2010, 39). In 2004, Deputy Prime Minister Victor Khristenko emphasized this dual importance of the Russian-led multilateralism in the former Soviet space by stating that "our goal is creating a structure that is essential for the world; a structure in which the world would not be able to function without Russia and the alliances involving it" (Khristenko 2004).

\section{Russia's Diplomatic Strategy}

To achieve its diplomatic goals, Russia has sought to expand its 'diplomatic space'. The latter is a central concept in diplomatic practice and can be thought of as the setting within which diplomacy and foreign policy are carried out. The concept conveys an idea of how decision-makers approach or perceive their operational environment (with its domestic, external and transnational components), and shape particular interests (Barston 2013, 39).

Diplomatic space is not static and may be gained or lost not only through the policies of other states but also as a result of the foreign policy choices of any given individual state. Diplomatic space may be augmented through various diplomatic strategies but, more fundamentally, as the Russian case indicates, it may be regained through foreign policy reorientation. Diplomatic space can be used to: develop a core set of foreign policy ideas; assist the projection of diplomatic reputation; ease external pressures; facilitate changes of direction; and support foreign policy initiatives (Barston 2013, 40). 
The institutional-legal dimension of diplomatic space is an important formal component. Activities in this area include: scaling up diplomatic representation, membership of international organizations, and an active role in both formal and informal multilateral settings (Barston 2013, 39-40). Indeed, Moscow has used a variety of diplomatic strategies to augment its diplomatic space and achieve its foreign policy objectives.

\section{Russia's 'Active Strategy'}

'Active strategy' refers to an overall foreign policy orientation which seeks to expand the role, activities, and influence of a state. Active strategy enables a state to become a leading regional player or operate at a global level as a broker, conduit for ideas, or problem solver (Barston 2013, 38). Examples of diplomatic methods and instruments pertaining to active strategy include the hosting of international events, the sponsoring or co-sponsoring of resolutions, and the undertaking of mediation initiatives (Ahtisaari and Rintakoski 2015; Barston 2013, 261-273; Berridge 2010, 235-252). Through the employment of an active strategy, states also pay particular attention to promoting ideas onto the international agenda through sponsoring of or participating in high-level meetings and similar fora (Groom 2015; Feinberg 2015; Meerts 2016).

Russia's active strategy includes elements of second-tier diplomatic strategies, including both 'cooperative strategy' and 'counter-strategy'. Cooperative strategy involves the seeking of support for a diplomatic initiative, such as the Russian proposal on the new security architecture in Europe (2008), and the building of bilateral and/or multilateral relations (Barston 2013, 33). Counter-strategies are political methods to develop bilateral support, build wider coalitions, or split a group or alliance (Barston 2013, 36). For example, Russian efforts to undermine NATO and the EU and strengthen the BRICS can be seen as parts of a counter strategy aimed at counter Western policies. Counter-strategies use a range of diplomatic instruments, such as public diplomacy and coercive diplomacy. Russia's use of mass media and social media are examples of how Moscow has sought to utilize public diplomacy in manipulating foreign publics and raising support for its policies, while Moscow's coercive tactics towards Eurasian states is indicative of Russia's efforts to reclaim political control of its former empire.

The Kremlin's pursuit of an active diplomatic strategy has expanded Moscow's international role, activities, and influence and has enabled Russia to become not only a leading regional player but also to operate at a global level as a great power that has to be taken seriously. Using a variety of active strategyrelated diplomatic methods, Russia has managed to promote its ideas onto the global level. Active strategy has also enabled Moscow to be at least moderately successful in placing items on the international agenda. 


\section{Russia's 'Expansion Strategy'}

In 'expansion strategy', states seek to extend their influence and expand their diplomatic space through participation in groupings and international organizations (Barston 2013, 38). A state's diplomatic space is extended through opening of new posts or raising the level of representation (Hamilton and Langhorne 2010, 202), as well as joining or creating new international organizations (Karns and Mingst 2015). Expansion strategy may rely on either 'quiet diplomacy' (step-by-step acquisition of membership) or on active and aggressive methods. Quiet diplomacy would use dialogue, special relationships, and creation of a bilateral axis in a regional grouping (Maley 2016). In contrast, a state pursuing a more active strategy would create a rival regional organisation.

Russia has sought to extend its diplomatic space through its participation in existing international organizations and the establishment of rival ones. Moscow has also created a bilateral axis in the regional groupings it has established in Eurasia. In other words, Russia has adopted an expansion strategy reflected in its participation to global international organizations and groupings, such as the IMF and WTO, the G-8 and G-20, and the BRICS. Moscow has also pursued an aggressive expansion strategy in the post-Soviet space by establishing regional organizations, such as the Eurasian Economic Union (EAEU), the Collective Security Treaty Organization (CSTO), and the Shanghai Cooperation Organization (SCO) to rival those of Europe as a way to counter the expansion of the EU and NATO toward Russia's traditional sphere of interest, demonstrate its power, and achieve regional dominance (Slobodchikoff 2014, 90).

\section{Russia's Diplomatic Methods}

To implement its diplomatic strategies, Russia has used the diplomatic modes of bilateral and multilateral diplomacy, as well as conference and summit diplomacy.

\section{Russia's Multilateral Diplomacy}

Multilateral diplomatic settings provide arenas for states in which participation not only demonstrates their sovereign equality but also enable them to project their views (Karns and Mingst 2015, 142). Multilateral diplomatic fora are also seen as the preferred vehicle for states to articulate concepts of international order and as the place where they could explore opportunities to create diplomatic alliances (Mahmubani 2015, 248). In this context, a variety of multilateral settings have provided Russia with a diplomatic space where Moscow has been able to project its views, articulate its preferred version of international order, and seek diplomatic support.

Russia's pursuit of multilateral diplomacy has dual characteristics. On the one hand, Moscow has sought to act as a proponent of diplomatic multilateralism at the global level with the aim of using existing multilateral institutions to 
restrain US policy. On the other hand, Russia has sought to assert itself as a regional power in the Eurasian region. Unlike its engagement with European organizations, such as the Council of Europe and the OSCE, in its immediate neighbourhood, Russia has sought to establish and use regional organizations to legitimize its actions and assert its dominance.

Russia regards multilateralism as a tool and its multilateral diplomatic engagement is shaped by its political, economic and security interests. Moscow views multilateral diplomacy as a means to create a multipolar international order and prevent the establishment of a unipolar world that is dominated by the United States. As we saw previously, the Russian doctrine of 'multi-polarity' has called for a policy that would target the strategic unity of the West and would provide the fertile ground for the development of an international order based on several centres of power (Mankoff 2007). In this context, Russia could play these 'centres' against one another and build flexible alliances with some emerging powers which might counter-balance the US' geopolitical dominance and ensure Russia's dominance in the post-Soviet space (Lee 2010, 33). In practice, Moscow's multilateral diplomacy has led to the enhancement and deepening partnerships with China and India, and has helped Russia to remain as the dominant actor in political, economic and security affairs in the Eurasian region.

Supported by the rising revenues from oil and gas, Russia's increasingly assertive foreign policy during the Putin Administration has shaped Moscow's multilateral diplomatic engagement (Tsygankov 2016, 177). Efforts to counter NATO expansion in the post-Soviet space via alternative, competitive regional multilateral organizations like the SCO and the CSTO can be understood as the manifestation of Russia's efforts to create a multipolar international order and ensure its dominant position in its immediate neighbourhood. Consequently, under Putin, Moscow's relationships within the former Soviet republics have become more substantial and comprehensive.

There are three international diplomatic fora which have been regarded by Moscow as the most appropriate for institutionalizing and practicing a collective leadership'. The first involves the UN, which, by granting special rights to the five permanent members of its Security Council, fits perfectly the criteria of the Russian concept of multilateralism. The second has been the G-8 from which Russia's membership has been suspended as a consequence of the annexation of Crimea. As a result, Moscow's preference has been shifted to the G-20. Last, but not least, Russia's active participation in the BRICS has raised Russia's global image and prestige as a great power. By working through these avenues, Moscow has managed to restrict considerably US unilateralism, as well as demonstrate Russia's equality with Western powers.

\section{Russia’s Bilateral Diplomacy}

There are several reasons for which some states may prefer to conduct their foreign policy through bilateral relations. One reason may have to do with historical links and alliance interests. Another reason is that bilateral diplomacy provides a sense of control and management (Rozental and Buenrostro 2015). A 
third reason is that power asymmetry between states provides the stronger state with certain advantages which would not be present if the same state had to deal with a set of states. Moreover, bilateral diplomacy enables states to target or develop links with other countries for political, economic, technical, or strategic purposes (Bayne and Woolcock, 2004, 167-8). Above all, the main characteristic of most bilateral special relations is the concern of one or both parties to retain exclusivity and reduce or eliminate the significance of access by other states. The principal disadvantages of bilateral diplomacy are that it is time consuming and limits international contacts, unless supported by multilateral initiatives. The routine care and maintenance of bilateral relations also requires significant commitments of organisation resources and may fragment expertise (Barston 2014, 41).

Russia's diplomatic strategy emphasize the use of multilateral diplomacy whenever international organizations can ease the process of obtaining its diplomatic objectives and provide additional legitimacy to its actions. However, Russia tends to act unilaterally or on the basis of bilateral arrangements whenever Moscow feels this would better serve its interests (Aris 2010). It may be argued that Moscow's preference for multilateral diplomacy applies to issues and areas not related to its 'near abroad'. In contrast, in its neighbourhood, Russia acts as a regional power and seeks to avoid a situation whereby its own freedom of action is restricted by its neighbouring states or through international organizations. Thus Russia views multilateral diplomacy as supplementary to or at most complementary with its bilateral strategy.

In sum, bilateral diplomacy is a tool that provides Moscow a sense of control and management of its relations with states in Russia's 'near abroad' and which also allows the Kremlin to exclude or reduce the significance of access by other international actors, such as the EU, the US and NATO. Yet, bilateral diplomacy enables Moscow to target or develop links with particular regional states for political, economic, and strategic purposes. Although bilateral relations imply a significant commitment of resources, oil and gas revenues has helped Moscow to invest substantially in the development of its regional bilateral relations.

\section{Standing Conferences: International Organizations}

In 2008, the new Foreign Policy Concept (FPC) of the Russian Federation was issued with the task of creating "a favourable external environment for the modernization of Russia" (RF 2008). The FPC provided the basis for the development of Russia's 'network' diplomacy that was to be based on two pillars: first, participation in various global and European organizations; and second, the establishment of flexible forms of interaction with different groups of countries in order to ensure compliance with the general interests. Consequently, international organizations, which constitute standing diplomatic conferences, have become one of Russia's most important diplomatic instruments. 


\section{Global International Organizations}

Russia's doctrine of 'multi-polarity' favors multilateral frameworks, so long as international organizations are not dominated by the West. Moscow's preference for multilateral diplomacy is associated with Russia's efforts to affirm great-power status and demonstrate that is one of the 'leading states.' For example, participation in the IMF and the WTO is seen by the Kremlin as a tool to increase the global visibility of Russia as a great power. As it was stated previously, Moscow prefers global affairs to be based on the leadership and multilateral interactions of few great powers, as long as Russia is included among them (Lee 2010, 36). Russia's rhetoric and behaviour in the UN exemplify this commitment to great-power governance.

\section{$\underline{\text { Regional International Organizations }}$}

When discussing Moscow's multilateral strategy, one has to distinguish between Russia's participation in European organizations, such as the Council of Europe, OSCE, and the European Bank for Reconstruction and Development (EBRD) on the one hand, and Russia's participation in Eurasian organizations, on the other. Russia's membership of the former, is an important aspect of Moscow's multilateral strategy but it is its central role in Eurasian organizations that is fundamental to achieving its foreign policy objectives.

Revealing its ambition and determination to act as a regional power in the post-Soviet space, Russia has engaged in the construction of multiple regional multilateral frameworks as a way to address the challenges to the status quo that arose as a result of the collapse of the Soviet Union and retain a dominant position in the region. In such regional initiatives, Moscow's instrumental use of multilateral diplomacy is evident. Prominent among these regional international organizations are the CIS (Commonwealth of Independent States), the SCO, and the CSTO. All these Eurasian organizations matters to Moscow because when states join Russian-led organizations they then legitimize Russian power. Furthermore, the resulted diplomatic space allows Russia to better facilitate changes in direction and support its foreign policy initiatives.

Particularly, the establishment of the CIS was one of Russia's major multilateral initiatives for the 'near abroad' in the 1990s (Malfliet, Verpoest and Vinokurov 2007). According to Janusz Bugajski (2004, 51), the CIS was "conceived as a mechanism to bind smaller and weaker neighbors closer to Russia and prevent their drifting permanently away from Moscow's orbit." Similarly, Donaldson and Nogee $(2002,178)$ argue that "the CIS is an instrument of Russian foreign policy" and a "mechanism for asserting Russian hegemony over the other eleven states." For Bugajski $(2004,54)$, the most important role that the CIS has played is that it has served as a "vehicle for political dominance" and has given "Russia a sense of continuity as a global power."

According to Kubicek $(2009,242)$, many of the ideals embodied in the CIS, such as respecting state sovereignty, renouncing the use of force or coercion, and coordinating economic policies, have been breached more than practiced. This is 
evident in the way Russia urged states to join, as not all former Soviet states were eager to become CIS members. For example, Georgia was the last member to join in 1993 as a result of Russian coercion, while the Moldovan Parliament refused to ratify CIS membership until 1994, and then it did only after imposition of punitive agricultural tariffs by Russia. Yet, Azerbaijan pulled out of the CIS in 1992, only to re-join the following year after a coup installed a pro-Moscow government (Kubicek 2009, 242).

The first Russian Military Doctrine (1992) embodied the assumption that the CIS would become a cohesive military mechanism, while a main goal of the 1993 FPC was to create a belt of security and good neighbourliness around Russia's borders through multilateral cooperation (Bobo 2002, 6-7; Mozaffari 1997, 4). In the 2000 National Security Concept (NSC), the weakening of the integration process in the CIS was defined as a threat. Consequently, the 2000 FPC gave a top priority to the CIS area and associated multilateral structures (Lee 2010, 39). Like the earlier concept, it sought to grapple with the loss of great-power status, looking for ways in which Russia could continue as a central player in world affairs. The strengthening of the CIS was, therefore, seen as means to this end. As we will see later, these Russian efforts eventually led to the establishment of the EAEU in 2015 .

\section{Summit Diplomacy}

Multilateral diplomacy within the framework of international organizations suits the powers with the greatest influence in them to have the world permanently reminded of their claims to high status (Berridge 2010, 146; Meerts 2016). At the same time, the organization of and participation in summits, which constitute multilateral non-standing international conferences, are seen by great powers as an important diplomatic method that help to augment the visibility of the organizing country, contribute to the increase of its diplomatic space, and allow the host state to set the diplomatic agenda (Berridge 2010, 162; Groom 2015; Feinberg 2015). Therefore, it is not a coincidence that Russia has sought membership in the G-7 and has played a central role in the G-20 and the BRICS. Moreover, getting the opportunity to organize and chair the G-8 meeting was regarded by the Russian leadership as a unique opportunity to demonstrate Russia's rising power and reassert its great power status. Likewise, Russia took the initiative to organize the first 'ministerial meeting' of the BRICS countries in 2006, as well as its first summit in 2009. These meetings not only allowed Russia to project globally its image as a great power but also had an important propaganda effect as Russian relations with the West were then low and thus showcased its relations with outside influential partners (Gabuev 2015).

\section{Russia's Diplomatic Instruments}

A variety of diplomatic instruments have been employed by Moscow to achieve its diplomatic objectives. Among those instruments, defence diplomacy, 
economic diplomacy, coercive diplomacy, public diplomacy, and asymmetrical diplomacy are featured more prominently in Russian diplomatic practice.

\section{Defence Diplomacy}

Although they may be used interchangeably, military diplomacy and defense diplomacy are not the same (Tan 2016, 592). 'Defense diplomacy' refers to the pursuit of a state's foreign policy objectives through the peaceful employment of defense resources and capabilities (Cheyre 2015). 'Military diplomacy' can be defined as a set of peaceful activities, carried out mainly by the representatives of the defense department, aimed at pursuing the foreign policy interests of the state in the field of security and defense policy (Tan 2016, 594). However, both instruments are essential for the establishment and promotion of security cooperation among countries (Holsti 2015; Barston 2013, 244-260). Moreover, due to the prominence of nuclear, chemical, and biological weapons among the available weaponry questions pertaining to arms control and disarmament, provide certain states with an opportunity to demonstrate their power status, increase their global visibility, and expand their diplomatic space (Johnson 2015).

Multilateral security cooperation provides the basis for assessing the multilateral dimension of Russian foreign policy since security relations constitute an arena in which Russia has performed relatively forcefully and successfully. Yet, it is Russia's military might that primarily underpins its bid for great power status. Alliances and multilateral security cooperation constitute cornerstones of this military prowess.

Specifically, three major aspects underpin Russia's multilateral diplomacy in the security field (Lee 2010, 40). First, military structures inherited from the Soviet Union were deployed across the entire post-Soviet space. Second, Moscow identified a range of security threats in neighbouring states, such as Islamic terrorism and ethnic conflict, which provided an additional incentive for Russia to enhance the defence capabilities of its neighbouring countries through regional multilateral cooperation (Trenin 2003, 121-122). Third, a significant degree of 'instrumentalism' has been featured prominently in Russia's security-related multilateralism.

A key purpose of Russia's multilateral efforts is Moscow's desire to secure the military allegiance of its neighbouring states. The aim has been to create a 'security belt' around the Russian Federation (Mozaffari 1997) and in this way, maintain Moscow's hegemonic presence on the Eurasian region. The CSTO and the SCO were set up in the 1990s in order to address the emerging regional security needs.

Specifically, shortly after the collapse of the Soviet Union, the Collective Security Treaty (CST) was established in May 1992 within the CIS framework. The initial aim was preserving a united security space that involved all the former Soviet states as well as preventing the total disintegration of what had been the Soviet military complex to the extent that is possible. The CST was eventually transformed into the CSTO in 2002 with Armenia, Belarus, Kazakhstan, Kyrgyzstan, Russia and Tajikistan serving as its members. The objective of this 
transformation was to have a full-fledged organization capable of addressing the new threats and challenges to the region through a joint military command located in Moscow, a rapid reaction force based in Central Asia (originally agreed upon in May 2001), and a common air defence system. These measures entailed a significant upgrade of the CSTO, and indicated the emergence of a 'reactive' form of Russian multilateralism directed against the US military presence in the region. The improvement in CSTO capabilities was spurred primarily by fears over the deteriorating security in Central Asia after the Islamic Movement of Uzbekistan (IMU) incursions in 1999 and 2001.

With the establishment of the CSTO, the member states pledged to better coordinate their foreign, security, and defence policies within the organization's framework (Lee 2010, 41). For this purpose, a political cooperation directorate was set up. In addition, a military cooperation directorate to manage military operations and a directorate to tackle common challenges and threats were established. In 2003, CSTO member states agreed to assign two reinforced battalions each (three in the case of Tajikistan), in permanent combat readiness to a standing rapid-reaction force.

CSTO has evolved since its inception and by 2007 the organization signed an agreement to cooperate on security, crime, and drug trafficking. Additionally, the CSTO developed peacekeeping forces to be used in the post-Soviet space to promote peace and stability (Slobodchikoff 2014, 86). However, most of the security threats to CIS states come from within the CIS itself, which in most cases, means Russia (Kubicek 2009, 242). In other words, the asymmetrical security structure in the region allows Russia to exert a degree of dominance over the other members thereby increasing their insecurity. This Russian strategy is further reinforced by the CSTO doctrine that "ensures the planning, procurement, and training would be controlled from Moscow and that Russian officers would dominate the collective staffs and joint forces" (Bugajski 2004, 61). In essence, the CSTO allows Moscow to expand its influence throughout the regional security structure by situating itself in positions of authority and leadership within the organization. Not only does this integrate Russian forces with other states in the region, but it also provides legitimacy to Russian military operations.

While the CSTO provides Moscow with a way to infiltrate the security realm in the region, it also furnishes Russia with a counter collective to combat NATO encroachment. Because Russia regards itself as the 'defender' of the region, it claims the right to station troops and preserve military bases in the post-Soviet space. Arguably, this action helps to solidify Russia's status as a great power by preserving 'its region' from what it considers to be external threats. As a result, any attempt by the West to 'lure' CIS states away from Russia's orbit is perceived by Russia as a direct security threat.

Russia has also taken steps toward achieving its objective of being perceived as a great power via its role in the SCO, which represents the transformation of what was initially known as The Shanghai Forum. The latter was emerged in 1996 to address border disputes and reduce tensions involving China, the new countries of Central Asia and Russia. During the late 1990s and early 2000s, the organization's mandate expanded significantly to encompass newly emerging 
threats that are related primarily to terrorism and religious extremism. While CIS and CSTO are multilateral institutions that largely serve to legitimize Russia's leadership ambitions in the region, the SCO functions more as an instrument for monitoring and mitigating any expansion of China's influence in Central Asia (Mankoff 2009, 270).

The SCO was established on June 15, 2001 by China, Kazakhstan, Kyrgyzstan, Tajikistan, Uzbekistan, and Russia. Other states joined the founding members with 'Observer Status,' such as Afghanistan, and Mongolia, and 'Dialogue Partners,' such as Turkey, Sri Lanka, and Belarus (the only non-Asian member). In a recent meeting on 9 June 2017 in Astana (Kazakhstan), India and Pakistan were formally awarded full membership.

Moscow has paid attention to the role that is to be performed by the SCO in bringing Russia, China, and most of the Central Asian states together. The SCO fulfills the security role in a similar way NATO does for the West. In essence, the creation of this rival regional organization allows Russian to not only expand its diplomatic space, but it also provides a way for Russia to contest US strategy. For example, a striking feature of Russia's activities within the SCO have been the initiatives to use this regional forum as a platform for generating joint statements that cautions against US unilateralism globally as well as against US engagement in Eurasia.

Despite challenges and failures, Moscow, views these organizations in terms of 'instrumental multilateralism,' for they are meant to serve the Russian diplomatic objectives as best they can. Indeed, these organizations strengthen Moscow's special role in the post-Soviet space and help Russia to legitimize its political and military role, especially in dealing with so-called frozen conflicts whenever this role is challenged by criticism - whether from outside or within the region. For example, the CSTO has been used by Russia to counter the criticism of countries like Georgia and Moldova that seek to replace Russian peacekeepers and negotiations mediators with representatives from the UN, the OSCE, the EU and NATO. Finally, these organizations serve as an argument in opposing the growing attraction of the EU to several states in the CIS, by demanding that the EU respects both the existing formats of negotiations on frozen conflicts and the existing integration initiatives within the CIS.

Last, but not least, Russia has used 'nuclear diplomacy' as a means to demonstrate its great power status and that it stands on an equal footing with the United States. For example, in terms of multilateralism, Russia has been a party to the Iranian Nuclear Agreement and an important actor in the Six Party Talks pertaining to the North Korean nuclear program. As far as the US-Russia bilateral nuclear relationship is concerned, in January 1993, Presidents George H. W. Bush and Boris Yeltsin signed START II Agreement. However the treaty did not take effect because the US Senate did not ratify the 1997 protocol and several ABM Treaty amendments, whose passage the Russian Duma established as a condition for START II's entry into force. START II was effectively shelved as a result of the 2002 U.S. withdrawal from the ABM treaty. In March 1997, Presidents Bill Clinton and Boris Yeltsin agreed to a framework for START III negotiations which were supposed to begin after START II entered into force, which never 
happened. On 24 May 2002, Presidents George W. Bush and Vladimir Putin signed the Strategic Offensive Reductions Treaty (SORT) also known as the Moscow Treaty. The treaty, which was approved by the Senate and Duma and entered into force on 1 June 2003 was replaced by the New START on 5 February 2011. Moscow's participation to all these nuclear initiatives and agreements show that when global security is at stake, Russia can act responsibly and as a global security guarantor.

\section{Economic Diplomacy}

Economic diplomacy has always been a very important diplomatic instrument (Woolcock and Bayne 2015; Bayne and Woolcock 2004). However, globalization and shifting power balances have made it even a greater tool in the hands of economically powerful states (Okano-Heijmans 2016, 553). In the evolution of economic diplomacy, the three strands of commercial diplomacy, trade diplomacy, and investment promotion are becoming increasingly interlinked (Mills 2015; Tussie 2015; Barston 2013, 159-182). Thus, membership of IMF and WTO are seen as strengthening Russia's global image as a great power.

Specifically, since the creation of the Russian Federation, economic diplomacy has been an essential part of the Russian foreign policy. Hence, several foreign policy documents have emphasized that effective economic diplomacy contributes to the success of market reforms in Russia, strengthening the country's position in foreign markets, expanding Russian participation in global and regional trade, and strengthening economic, monetary, financial, and investment cooperation (Zonova 2016, 340). The two key priorities of Russian economic diplomacy have been stimulating foreign trade and attractive foreign direct investment. In addition, being a large exporter of oil and gas, 'energy diplomacy' has been of particular importance to Russia.

Russian economic diplomacy has been realized both on bilateral and multilateral basis, including frameworks of international and regional economic organizations. As far as global financial institutions are concerned, in 2016 Russia entered the list of the Top-10 IMF member states, which have the largest quota and voting share of the Fund, meaning more power and a greater say as the lender of last resort. In 2012, Russia joined the World Trade Organization (WTO). This accession was seen as a major step for Russia's further integration into the world economy as it would facilitate investment and trade, help to accelerate the modernization of the Russian economy and offer plenty of business opportunities for Russian companies.

Russia has sought to promote regional integration through the creation of regional economic organizations. Specifically, on 10 October 2000, when reforms on the CIS were reached the Eurasian Economic Community (EurAsEC) was formed with the purpose of erasing the failures of the CIS; creating a single market where members worked collectively to establish free trade zones and lower barriers to trade; meeting the challenges of globalization; and resuming the integration processes within the CIS (Slobodchikoff 2014, 76). Very quickly, the EurAsEC emerged as the economic complement of the CSTO. 
An interesting aspect of the EurAsEC has been its internal governing structure, which includes an 'Integration Committee' made up of the deputy heads of governments of member states who are responsible for "ensuring free trade among member states and identifying further possibilities for integration" (Slobodchikoff 2014, 76). What is interesting here is that this Committee does not require each decision to be unanimous and instead only needs a $2 / 3$ of the votes to pass. However, like in the case of the IFM, the votes are distributed based on which state pays more into the EurAsEC budget. As it pays the most, Russia gets enough votes to control the decision-making.

EurAsEC's moderate success led to the creation of the Eurasian Development Bank in 2006 with the support of Vladimir Putin. What is important to note here is the means with which this bank was able to develop, function, and support itself. While the purpose of the bank was to promote further regional economic coordination, business associations in Russia dominated its list of sponsors, particularly, the Russian Chamber of Industry and Trade, the Russian Alliance of Manufacturers and Businesspeople, and the Association of the Financial and Industrial Groups of Russia. This self-centered tactic by Russia usurps the supposed cooperative nature of the organization in order to exert its influence. In other words, by installing its own sponsors Russia was able to control the operation of the organization.

In 2004, Russia joined the Central Asian Economic Community (CAEC) to strengthen its presence in Central Asia. Soon after, Russia sought to consolidate the multilateral landscape in parts of Eurasia by dissolving the CAEC in the EurAsEC, which led other members of the CAEC to negotiate and eventually merge the two organizations. This merger was to provide the Eurasian region with considerable coherence and improve the EurAsEC's prospects of becoming a more important platform for Eurasian cooperation and coordination as member states wanted the organization to become a viable economic bloc between the EU in the West and the ASEAN in the East.

Following the relative success of the EurAsEC, the Eurasian Customs Union (EACU) came into existence in January 2010. Headed by Russia, Belarus, and Kazakhstan, with Kyrgyzstan and Armenia later joining, the purpose of the EACU was to "comprehensively upgrade, raise the competitiveness of and cooperation between the national economies, and to promote stable development in order to raise the living standards of ...Member States" (EACU 2017).

The establishment of the EACU was initially seen as Russia's attempt to contest WTO membership. In Moscow's view, the establishment of an alternative regional trade organization it would allow Russia to represent the CIS in its relations with the WTO, thus projecting its great power status. For the Kremlin, "claims to great power status will only be taken seriously if the CIS acts as one coordinated body...” (Bugajski 2004, 56).

By January 1, 2015, the EurAsEC and the EACU were absorbed into the EAEU, with the purpose of integrating the economies of post-Soviet states and creating a powerful trading bloc, much like the EU. Bearing resemblance to the EU, the EAEU introduces the free movement of goods, capital, services and people and provides for common policies in macroeconomic sphere, transport, 
industry and agriculture, energy, foreign trade and investment, customs, technical regulation, competition and antitrust regulation. Provisions for a single currency and greater integration are also envisioned. Although the EAEU operates through supranational and intergovernmental bodies, Russia remains the dominant force in this organization.

Russian efforts to expand its diplomatic space also took place through Moscow's efforts to establish a common CIS energy space. One of the ways Russia attempted to do this was through the practice of swapping the debts of CIS members for Russian equity in their energy and strategic sectors (Blank 2003, 12). For example, in March 2003, the Russian energy company Gazprom prepared to reduce the price of gas to Moldova in return for allowing Russian business to buy up assets. At the time, Moldova's debt for gas delivery was \$121.1 million and Gazprom wanted to swap the debt for ownership of several Moldovan companies (Bugajski 2004, 101-102).

In November 2002, Gazprom claimed Belarus received a "gas overdraft" and threatened to halt its gas supply if they refused to pay a higher premium than the amount contracted (Lelyveld 2002). According to Belarusian President Aleksandr Lukashenko, the cut in energy supplies was a political decision by the Kremlin, because Gazprom wanted shares in Beltranshaz as repayment for the Belarus gas debt (Bugajski 2004, 67). Even though Lukashenko's rhetoric was condemning, Minsk still succumbed to Russian pressure and signed an intergovernmental agreement in April 2002 to expand cooperation in the gas sector. Securing these transport lines ensures Russia's energy and economic dominance in the region. The swaps for debt transactions only "mask hegemony behind the rhetoric of regional integration and cooperation" (Blank 2003, 2).

\section{Coercive Diplomacy}

Coercive diplomacy aims to compel changes in behaviour using threats, sanctions and withdrawal or denial of rewards (Barston 2013, 46; Jacobsen 2016, 479). However, coercive action moves diplomacy into a grey area since diplomacy becomes an instrument of coercive behaviour, rather than exchange and adjustment that is conducted through discussion, mediation, or pacific settlement. Coercive diplomacy should be distinguished from the actual use of force. For example, Russia's military operations in Syria do not constitute an example of coercive diplomacy.

Moscow's foreign policy is based on traditional notions of strength and power and its objective is to project Russian power. To achieve its foreign policy objectives and reclaim political control of its former empire, Russia utilizes coercive diplomacy. It seems that any former Soviet state that has attempted to pursue an independent foreign policy or align with other power centers and especially the American-dominated West, has experienced the brunt of Russia's coercion for diplomatic subversion. Uzbekistan and Belarus are cases in point. However, Russia's coercive diplomacy seems to apply exclusively to its regional sphere of influence (near abroad) while Moscow's power politics tactics appears to be limited to instances where it has a long-standing rivalry, the public supports 
such action, when there are salient foreign policy issues at stake and depending on the location (Maness and Valeriano 2015).

\section{Public Diplomacy}

'Public diplomacy' is conceptualized as information-messaging, cultural projection and international reputation management (Huijgh 2016, 444; Mellisen 2015). The term constitutes the modern form for what is widely known as propaganda and which is directed chiefly, albeit not exclusively at foreign publics. The aim is to influence political outcomes in foreign countries by manipulating public opinion. As a result, communication and media have become important diplomatic tools (Barston 2013, 34-35).

The idea of establishing and projecting diplomatic presence has become a much more important feature of contemporary diplomacy. In part, the reason for this is the growth in associated media technologies, which make information dissemination much easier than before. Particularly, the growth of online news has affected several aspects of the communication process, particularly pace. An aggressive media strategy based on acquiring media outlets, stations or dominating search engine or by being the default criteria may create greater diplomatic presence and influence.

Although traditionally public diplomacy relied on the use of mass media (press and television), the new public diplomacy relies on the use of 'digital diplomacy' (Gilboa 2016; Copeland 2015; Bjola and Holmes 2015; Karagulle 2017; Deruda 2015) and cultural diplomacy (Goff 2015). Digital diplomacy includes the use of social media, such as twitter, Facebook, YouTube, Google, Instagram and LinkedIn by governments to achieve their foreign policy objectives. Cultural diplomacy also includes 'sports diplomacy'; a tool that states occasionally use to achieve foreign policy goals. Particularly, mega sports events, such as the Olympic Games or the World Cup offer multiple public diplomacy opportunities, help increase the international visibility of the host country, and strengthen its positive image abroad (Murray 2016, 620). Moreover, sporting events create leadership summit opportunities for diplomatic engagement (Black and Peacock 2015).

Russia's diplomatic strategy has demonstrated the importance of communication and media strategy in diplomacy. Russia's aggressive media strategy not only includes the establishment and operation of the Russia Today (RT) television channel the aim of which is to propagate Moscow's ideas and positions world-wide, but also the acquisition of media outlets and stations in its neighbouring states and their use as a means of diplomatic propaganda, particularly during electoral periods. Yet, as Moscow's interference in the American Presidential elections, as well as in some European elections indicate, Russia has been very effective in using the social media and the cyberspace to influence and determine political outcomes in other countries. Moreover, Moscow has viewed the 2014 Winter Olympic Games in Sochi and the 2018 World Cup as opportunities to increase Russia's global visibility and demonstrate its capacity to organize successfully very prestigious mega sporting events. 


\section{Asymmetrical Diplomacy}

Russia's diplomatic strategy has also demonstrated the importance of what I would call 'asymmetrical diplomacy'. Diplomacy refers to the conduct of international relations by professional diplomats (Bull 1977, 156). However, Bull's definition of diplomacy also refers to the conduct of relations between states and other entities. Therefore, nothing in Bull's definition precludes the interaction between the diplomatic representatives of a state and a political organization within another state (asymmetrical diplomacy). For example, in its efforts to determine political outcomes that favours its policies and ideas, Russia has established a network of relations with political parties in various countries. The goal here is to assist friendly political parties to come on power or becoming highly influential in domestic politics. In return, Moscow expects from those friendly parties either active support for Kremlin's positions and policies or, at least, to refrain from or prevent the imposition of political barriers. For example, the National Front in France was in close contact with Kremlin during the last French Presidential election and Marine Le Pen travelled to Moscow to meet President Putin who provided open support for her party. Similar linkages exist between the Kremlin and other political parties in Europe while the relations between the Russian Ambassador in Washington DC and members of the Trump Administration is also illustrative of this type of asymmetrical diplomacy.

\section{Conclusion}

The purpose of this article was to utilize diplomatic theory to identify and explore Russia's diplomatic strategy. In doing so, it identified Russia's diplomatic goals, examined Moscow's diplomatic strategy, and discussed the diplomatic methods and instruments employed by the Kremlin to achieve Russia's diplomatic objectives.

Moscow's diplomatic goals in the post-Cold war era have been the maintenance of Russia's status and prestige as a great power; its participation in the management of international affairs on an equal footing with the US; and the restriction of the influence and presence of Western countries in the former Soviet space.

Central to Russia's efforts to re-negotiate the post-Cold War international order has been the doctrine of 'multi-polarity' whose key characteristics include: first, the collective management of world affairs by great powers including Russia; second, influence and dominance in the former Soviet area as a means of globally enhancing Russia's great-power status; third, Moscow's active engagement in the 'near abroad'; fourth, balancing the introduction of market principles with the perceived imperative to entrench Russian leadership; and finally, a reactive and competitive regional multilateralism in response to Western encroachment in the Eurasian region. 
Russia has pursued an active and expansive diplomatic strategy utilizing the methods of multilateral, bilateral, conference, and summit diplomacy. To achieve its diplomatic objectives, Russia has employed a variety of diplomatic instruments, such as economic diplomacy, public, coercive, asymmetrical, and defence diplomacy all of which have allowed Russia to re-emerge as a great power that needs to be taken seriously.

While presenting itself as a proponent of multilateralism, Russia largely acts as an 'instrumental multilateralist' that seeks to pursue its objectives and legitimize its role and activities within the Eurasian region through organizations that Moscow was instrumental in establishing. Russia-led multilateralism in the postSoviet space is becoming increasingly substantial and regional international relations of the Eurasian region are increasingly defined by a consolidation and solidification of Russian dominated multilateral structures. In turn, becoming a regional hegemonic power has allowed Russia to add to its diplomatic weight as a great power.

\section{References}

Ahtisaari, Martti and Rintakoski, Krisitna. (2015). Mediation. In Andrew F. Cooper, Jorge Heine and Ramash Thauker (Eds.), The Oxford Handbook of Modern Diplomacy (pp. 337-351). Oxford: Oxford University Press.

Aris, Stephen. (2011). Eurasian Regionalism: The Shanghai Cooperation Organization. London: Palgrave.

Aris, Stephen. (2010). Russia's Approach to Multilateral Cooperation in the Post-Soviet Space: CSTO, EurAsEC and SCO. Russian Analytical Digest, 76, 2-4.

Astrov, Alexander. (Ed.) (2011). The Great Power (Mis)Management: The RussianGeorgian War and Its Implications for Global Political Order. Aldershot: Ashgate.

Baev, Pavel K. (2009). Leading in the Concert of Great Powers: Lessons from Russia's G8 Chairmanship. In Elana Wilson Rowe and Stina Torjesen (Eds.), The Multilateral Dimension in Russian Foreign Policy (pp. 58-68). London: Routledge.

Barston, Ronald P. (2014). Modern Diplomacy. New York: Routledge.

Bayne, Nicholas and Woolcock, Stephen. (2004). The New Economic Diplomacy. Ashgate, Aldershot.

Berridge, Geoffrey R. (2010). Diplomacy: Theory and Practice. $4^{\text {th }}$ edition. London: Palgrave.

Bjola, Corneliu and Lu Jiang. (2015). Social Media and Public Diplomacy. In Corneliu Bjola and Marcus Holmes (Eds.), Digital Diplomacy: Theory and Practice (pp. 7188) London: Routledge.

Black, David and Peacock, Byron. (2015). Sports and Diplomacy. In Andrew F. Cooper, Jorge Heine and Ramash Thauker (Eds.). The Oxford Handbook of Modern Diplomacy (pp. 708-727). Oxford: Oxford University Press.

Blank, Stephen. (2003). Benign Hegemony: Russia's Grand Delusion. Perspective, 14(1), $1-12$.

Bobo, Lo. (2002). Russian Foreign Policy in the Post-Soviet Era: Reality, Illusion and Mythmaking, Basingstoke: Palgrave.

Braun, Aurel. (ed.) (2008). NATO-Russia Relations in the Twenty-First Century. London: Routledge.

Bugajski, Janusz. (2004). Cold Peace: Russia's New Imperialism. Westport, CT: 
Greenwood Publishing Group.

Bull, Hedley. (1977). The Anarchical Society. New York: Columbia University Press.

Cherye, Juan Emilio. (2015). Defense Diplomacy. In Andrew F. Cooper, Jorge Heine and Ramash Thauker (Eds.), The Oxford Handbook of Modern Diplomacy (pp. 369-384). Oxford: Oxford University Press.

Copeland, Daryl. (2015). Digital Technology. In Andrew F. Cooper, Jorge Heine and Ramash Thauker (Eds.), The Oxford Handbook of Modern Diplomacy (pp. 453-472). Oxford: Oxford University Press.

Deruda, Antonio. (2015). Digital Diplomacy. CreateSpace Publishing.

Donaldson, Ronald H., and Nogee, Joseph, L. (2002). The Foreign Policy of Russia: Changing Systems, Enduring Interests. Armonk, N.Y.: M.E. Sharpe.

Eurasian Economic Union. February 7, 2017. http://www.eaeunion.org/?lang=en\#about.

Feinberg, Richard. (2015). Institutionalized Summitry. In Andrew F. Cooper, Jorge Heine and Ramash Thauker (Eds.), The Oxford Handbook of Modern Diplomacy (pp. 303318). Oxford: Oxford University Press, 303-318.

Gabuev, Alexander. (2015). Russia cements lead role with BRICS presidency." Russia Beyond the Headlines. May 25, 2015. https://www.rbth.com/opinion/2015/05/25/rus sia_cements_lead_role_with_brics_presidency_46287.html.

Gilboa, Eytan. (2016). Digital Diplomacy. In Costas, M. Constantinou, Pauline Kerr and Paul Sharp (Eds.), The Sage Handbook of Diplomacy (pp. 540-551). London: Sage.

Goff, Patricia. (2015). Cultural Diplomacy. In Andrew F. Cooper, Jorge Heine and Ramash Thauker (Eds.). The Oxford Handbook of Modern Diplomacy (pp. 419-435). Oxford: Oxford University Press.

Groom, A.J.R. (2015). Conference Diplomacy. In Andrew F. Cooper, Jorge Heine and Ramash Thauker (Eds.). The Oxford Handbook of Modern Diplomacy (pp. 263-277). Oxford: Oxford University Press.

Hamilton, Keith and Langhorne, Richard. (2010). The Practice of Diplomacy. $2^{\text {nd }}$ edition. London: Routledge.

Holsti, Kalevi J. (2015). In Andrew F. Cooper, Jorge Heine and Ramash Thauker (Eds.). The Oxford Handbook of Modern Diplomacy (pp. 577-592). Oxford: Oxford University Press.

Huijgh, Ellen. (2016). Public Diplomacy. In Costas, M. Constantinou, Pauline Kerr and Paul Sharp (Eds.), The Sage Handbook of Diplomacy (pp. 437-450). London: Sage.

Hunter, Dhireen T. (1996). Central Asia since Independence. London: Praeger.

Jacobsen, Peter Viggo. (2016). Coercive Diplomacy. In Costas, M. Constantinou, Pauline Kerr and Paul Sharp (Eds.), The Sage Handbook of Diplomacy (pp. 476-486). London: Sage.

Johnson, Rebecca (2015). Arms Control and Disarmament. In Andrew F. Cooper, Jorge Heine and Ramash Thauker (Eds.). The Oxford Handbook of Modern Diplomacy (pp. 593-609). Oxford: Oxford University Press.

Karagulle, Akin Emre. (2017). Digital Diplomacy. CreateSpace Publishing.

Karns, Margaret P. and Mingst, Karen A. (2015). International Organizations and Diplomacy. In Andrew F. Cooper, Jorge Heine and Ramash Thauker (Eds.). The Oxford Handbook of Modern Diplomacy (pp. 142-159). Oxford: Oxford University Press.

Khristenko, V. (2004). Making headway to integration. Russia in Global Affairs, no. 1. http://eng.globalaffairs.ru/number/n_2573

Kubicek, Paul. (2009). The Commonwealth of Independent States: an example of failed regionalism? Review of International Studies, 35, 237-256.

Lapidus, Gail. (1992). From democratization to disintegration: the impact of perestroika on the national question.” In Gail Lapidus, Victor Zaslavsky, and Philip Goldman 
(Eds.), From Union to Commonwealth: Nationalism and Separatism in the Soviet Republics (pp. 45-70). Cambridge: Cambridge University Press.

Lee, Hongsub. (2010). Multilateralism in Russian Foreign Policy: Some Tentative Evaluations. International Area Review, 13(3), 31-49.

Mahbubani, Kishore. (2015). Multilateral Diplomacy. In Andrew F. Cooper, Jorge Heine and Ramash Thauker (Eds.). The Oxford Handbook of Modern Diplomacy (pp. 248262). Oxford: Oxford University Press.

Maley, William (2016). Quiet and Secret Diplomacy. In Costas, M. Constantinou, Pauline Kerr and Paul Sharp (eds.), The Sage Handbook of Diplomacy (pp. 451-460). London: Sage.

Malfliet, Kaitlijn, Verpoest, Lien and Vinokurov, Evgeny. (2007). The CIS, the EU and Russia. London: Palgrave.

Makarychev, Andrey and Morozov, Viatcheslav. (2011). Multilateralism, Multipolarity, and Beyond: A Menu of Russia's Policy Strategies. Global Governance, 17, 353-373.

Maness, Ryan C. and Valeriano, Brandon. (2015). Russia's Foreign Policy Choices and the Application of Situational Coercive Diplomacy. In Ryan C. Mannes and Brandon Valeriano (Eds.), Russia's Coercive Diplomacy (pp. 21-44). New York: Springer.

Mankoff, Jeffrey. (2009). Russian Foreign Policy: The Return of Great Power Politics, New York: Rowman \& Littlefield Publishers.

Mankoff, Jeffrey. (2007). Russia and the West: Taking the Longer View. The Washington Quarterly, 30(2), 13-135.

Mellisen, Jan. (2015). Public Diplomacy. In Andrew F. Cooper, Jorge Heine and Ramash Thauker (Eds.). The Oxford Handbook of Modern Diplomacy (pp. 436-452). Oxford: Oxford University Press.

Meerts, Paul. (2016). Conference Diplomacy. In Costas, M. Constantinou, Pauline Kerr and Paul Sharp (Eds.), The Sage Handbook of Diplomacy (pp. 499-509). London: Sage.

Mills, Gregg (2015). Trade and Investment Promotion. In Andrew F. Cooper, Jorge Heine and Ramash Thauker (Eds.). The Oxford Handbook of Modern Diplomacy (pp. 402418). Oxford: Oxford University Press.

Morozov, Viatcheslav. (2008). Sovereignty and Democracy in Contemporary Russia: A Modern Subject Faces the Post-Modern World. Journal of International Relations and Development 11, 152-180.

Morozov, Viatcheslav. (2002). Resisting Entropy, Discarding Human Rights: Romantic Realism and Securitization of Identity in Russia. Cooperation and Conflict, 37, 409430.

Mozaffari, Mehdi. (1997). The CIS' Southern Belt: A New Security System. In Mehdi Mozaffari (Ed.), Security Politics in the Commonwealth of Independent States (pp. 334). London: Macmillan.

Okano-Heijmans, Maaike. (2016). Economic Diplomacy. In Costas, M. Constantinou, Pauline Kerr and Paul Sharp (Eds.), The Sage Handbook of Diplomacy (pp. 552-563). London: Sage.

Powers, Shawn. (2015). Media, Diplomacy and Geopolitics. In Andrew F. Cooper, Jorge Heine and Ramash Thauker (Eds.). The Oxford Handbook of Modern Diplomacy (pp. 209-228). Oxford: Oxford University Press.

Rozenthal, Andres and Alicia Buenrostro. (2055). Bilateral Diplomacy. In Andrew F. Cooper, Jorge Heine and Ramash Thauker (Eds.). The Oxford Handbook of Modern Diplomacy (pp. 229-247). Oxford: Oxford University Press.

Putin, Vladimir (2007). Speech and the Following Discussion at the Munich Conference on Security Policy, 10 February 2007, http://archive.kremlin.ru/eng/speeches/2007/ 02/10/0138_type82912type82914type82917type84779_ 118123.shtml. 
RFE/RL's Kazakh Service. (2017). "Pakistan, India Join Shanghai Cooperation Organization." Radio Free Europe/Radio Liberty. June 9, 2017. https://www.rferl.org/a/shang hai-cooperation-organization-meeting-astana/28537493.html.

Rumer, Eugene, Trenin, Dimitri and Zhao, Huasheng. (2007). Central Asia. New York: M.E. Sharpe.

Russian Federation/RF. (2008). The Foreign Policy Concept of the Russian Federation. http://en.kremlin.ru/supplement/4116

Sharp, Paul. (2011). Diplomatic Theory of International Relations. Cambridge. Cambridge University Press.

Slobodchikoff, Michael O. (2014). Building Hegemonic Order Russia's Way: Order, Stability, and Predictability in the Post-Soviet Space. London: Lexington Books.

Steiner, Barry, H. (2018). Diplomatic Theory. Lanham, MD: Rowman and Littlefield.

Stivachtis, Yannis A. (2015). Liberal Democracy, market economy, and international conduct as standards of 'civilization' in contemporary international society: The case of Russia's entry into the 'community of civilized states'. Journal of Eurasian Studies, 30, 1-13.

Tan, See Seng (2016). Military Diplomacy. In Costas, M. Constantinou, Pauline Kerr and Paul Sharp (Eds.), The Sage Handbook of Diplomacy (pp. 591-600). London: Sage.

Timmermann, Hans. (1992). Russian foreign policy under Yeltsin: priority for integration into the 'community of civilized states'. The Journal of Communist Studies, 8(4), 163185.

Trenin, Dmitri. (2003). Southern Watch: Russia's Policy in Central Asia. Journal of International Affairs, 56(2), 119-131.

Tsygankov, Andrei P. (2016). Russia's Foreign Policy: Change and Continuity in National Identity. $4^{\text {th }}$ edition. Lanham, MD: Rowman and Littlefield.

Tsygankov, Andrei P. (2012). Russia and the West from Alexander to Putin. Cambridge: Cambridge University Press.

Tussie, Diana. 92015). Trade Diplomacy. In Andrew F. Cooper, Jorge Heine and Ramash Thauker (Eds.). The Oxford Handbook of Modern Diplomacy (pp. 625-641). Oxford: Oxford University Press.

Wilson Rowe, Elena and Torjesen, Stina. (Eds.) (2009). The Multilateral Dimension in Russian Foreign Policy. London: Routledge.

Woolcock, Stephen and Nichoas Bayne. (2015). Economic Diplomacy. In Andrew F. Cooper, Jorge Heine and Ramash Thauker (Eds.). The Oxford Handbook of Modern Diplomacy (pp. 385-401). Oxford: Oxford University Press.

Zonova, Tatiana. (2016). Russian post-Soviet Diplomacy. In Costas, M. Constantinou, Pauline Kerr and Paul Sharp (Eds.), The Sage Handbook of Diplomacy (pp. 336-347). London: Sage. 